\title{
Photosynthetic acclimatization to cyclical water deficit in rubber tree seedlings
}

\author{
Aclimatação fotossintética ao déficit hídrico cíclico em mudas de \\ seringueira
}

José Eduardo Macedo Pezzopane ${ }^{1}$ (D), Jessily Medeiros Quaresma (D), Mariana Duarte Silva Fonseca ${ }^{1}$ (D), Rogério de Souza Nóia Junior ${ }^{2}$ (D), Talita Miranda Teixeira Xavier ${ }^{1}$ (D), Genilda Canuto Amaral ${ }^{1}$ (D), Paulo Cezar Cavatte ${ }^{1}$ (D), Jonas Souza Vinco ${ }^{1}$ (1)

${ }^{1}$ Universidade Federal do Espírito Santo - UFES, Jerônimo Monteiro, ES, Brasil

${ }^{2}$ Technical University of Munich - TUM, Freising, Germany

How to cite: Pezzopane, J. E. M., Quaresma, J. M., Fonseca, M. D. S., Nóia Junior, R. S., Xavier, T. M. T., Amaral, G. C., Cavatte, P. C., \& Vinco, J. S. (2022). Photosynthetic acclimatization to cyclical water deficit in rubber tree seedlings. Scientia Forestalis, 50, e3705. https://doi.org/10.18671/scifor.v50.03

\begin{abstract}
Plants subjected to successive water deficit cycles may be able to rapidly develop acclimatization responses. Thus, the objective of this study was to analyze the acclimatization capacity of the photosynthetic machinery of rubber tree seedlings submitted to water deficit cycles (WDC). To do so, we designed four treatments: control plants (fully irrigated, CT); OP (not previously submitted to any WDC); 1P (previously submitted to one WDC); and 2P (previously submitted to two WDC). The water deficit cycle was characterized by suspending irrigation until rubber tree net assimilation rate $(A)$ reached zero $(A \leq 0)$. Then the plants were rehydrated until substrate moisture reached its maximum water retention capacity, and the irrigation was maintained until the rate $A$ of the plants recovering from water deficit reached $90 \%$ of the rate of the control plant, and then a new cycle of water deficit started again. In the third and last cycle (WDC3), treatments OP, 1P and 2P were simultaneously subjected to water deficit and comparative eco-physiological evaluations between treatments when each group of plants reached $A \leq 0$. After WDC3, $2 \mathrm{P}$ plants achieved greater $A$, stomatal conductance, transpiration and intrinsic efficiency of water use after 21 days, compared to $1 \mathrm{P}$ and $\mathrm{OP}$ plants. The leaves of treatments $2 \mathrm{P}$ and $\mathrm{OP}$ showed the same relative water content (RWC), higher photosynthetic pigment concentration, and 2P showed greater water absorption capacity in the substrate under low water availability, maintaining high A values in comparison with the other treatments 36 days after the start of WDC3. The results indicate that the 2P plants showed acclimatization of the photosynthetic machinery in maintaining a positive carbon balance when subjected to WDC, indicating that leaf turgor was maintained through cellular and osmotic adjustment, accumulation of photosynthetic pigments and greater soil water absorption capacity.
\end{abstract}

Keywords: Hevea brasiliensis; Gas exchanges; Drought; Water management.

\section{Resumo}

Plantas submetidas a sucessivos ciclos de déficit hídrico podem desenvolver respostas de aclimatação rapidamente. Assim, o objetivo foi analisar a capacidade de aclimatação da maquinaria fotossintética de mudas de seringueira submetidas ao déficit hídrico cíclico (DHC). Para isso foram testados quatro tratamentos: plantas controle (irrigadas constantemente); OP (não submetido anteriormente a DHC); 1P (previamente submetido a um $\mathrm{DHC}$ ); e $2 \mathrm{P}$ previamente submetido a dois $\mathrm{DHC}$ ). Foram aplicados três DHCs, caracterizados por uma fase inicial onde a irrigação foi suspensa até que a taxa de assimilação líquida das plantas $(A)$ atingissem zero $(A \leq 0)$, e a fase final quando a água atingisse sua capacidade máxima de retenção de água no substrato. Um novo ciclo foi iniciado somente quando a taxa de $A$ das plantas com déficit hídrico, após a reidratação, atingiu 90\% da taxa de $A$ das plantas controle. No terceiro

Financial support: This study was financed in part by the Coordenação de Aperfeiçoamento de Pessoal de Nível Superior - Brasil (CAPES) - Finance Code 001. Conflict of interest: Nothing to declare.

Corresponding author: genildacanuto@gmail.com

Received: 26 April 2021.

Accepted: 22 December 2021.

Editor: Mauro Valdir Schumacher

(c) (i) This is an Open Access article distributed under the terms of the Creative Commons Attribution License, which permits unrestricted use,

c) distribution, and reproduction in any medium, provided the original work is properly cited. 
e último ciclo (DHC3), os tratamentos OP, 1P e 2P foram submetidos simultaneamente ao déficit hídrico e realizado avaliações ecofisiológicas comparativas entre os tratamentos quando cada grupo de plantas atingiu $A \leq 0$. Após $\mathrm{DHC}$, as plantas $2 \mathrm{P}$ apresentaram maior $A$, condutância estomática, transpiração $\mathrm{e}$ eficiência intrínseca do uso da água após 21 dias, em comparação com as plantas 1P e OP. As folhas dos tratamentos $2 \mathrm{P}$ e $\mathrm{OP}$ apresentaram o mesmo teor relativo de água, maior concentração de pigmentos fotossintéticos e 2P apresentaram maior capacidade de absorção de água no substrato sob baixa disponibilidade hídrica, mantendo elevados valores de $A$, em comparação com os demais tratamentos, 36 dias após o início do DHC3. Os resultados indicam que as plantas 2P apresentaram aclimatação da maquinaria fotossintética mantendo o balanço de carbono positivo quando submetidas à $\mathrm{DHC}$, indicando que o turgor foliar foi mantido por meio de ajuste celular e osmótico, acúmulo de pigmentos fotossintéticos e maior capacidade de absorção de água no solo.

Palavras-chave: Hevea brasiliensis; Trocas gasosas; Seca; Gestão da água.

\section{INTRODUCTION}

Future increase of atmospheric $\mathrm{CO}_{2}$ concentrations will result in increased temperatures (Intergovernmental Panel on Climate Change, 2021), and this can alter rainfall distribution (Kimball et al., 2001; Reich et al., 2016) and atmospheric vapor pressure deficit (VPD), resulting in more frequent and severe droughts (Intergovernmental Panel on Climate Change, 2021). Extreme and severe droughts are a major limitation for forest cultivation in Brazil, being the main cause of forest productivity losses in $87 \%$ of the producing areas in the southeastern region of the country (Elli et al., 2019; Freitas et al., 2021). The increased frequency of extreme weather events, such as drought, due to climate change threatens national forest production. Understanding plant photosynthetic machinery acclimatization to these extreme events is key to minimize carbon losses and to adapt to a changing climate. In this sense, supplying previous water shortage stimuli at the initial development phase may induce alteration in the metabolism which allows the plant to respond faster and withstand recurring droughts (Bruce et al., 2007).

Recent eco-physiological studies have reported that the plants present more efficient responses when submitted to cyclical water deficit due to an increase in photo-protection (Walter et al., 2011), and in the transcription rate of genes related to stress response (Ding et al., 2012). Eucalyptus seedlings responded to water deficits by increasing root biomass and reducing the size and stomata size, recovering faster from subsequent water deficits (Nóia Júnior et al., 2020a). However, studies on the acclimatization process in plants to successive episodes of water deficit are still recent and need more understanding of ecophysiological processes (Nóia Júnior et al., 2020a; Amaral et al., 2021), mainly for important forest species such as rubber trees.

The rubber tree (Hevea brasiliensis Muell.-Arg.) is a tree species native to South America and tapping its natural latex has led to its spreading to other regions in the world, mainly Southeast Asia (Venkatachalam et al., 2009). The optimum growth rate in the rubber tree occurs when the air temperature is around $28^{\circ} \mathrm{C}$ (Kositsup et al., 2009). Rubber tree crop planting in Brazil takes place in the late spring and early summer, when optimum temperature and water availability occur (Alvares et al., 2013). However, due to climatic variability, long dry periods have constantly occurred after planting new crops (Nóia Júnior et al., 2020b), and rubber trees are constantly submitted to drought events (Clermont-Dauphin et al., 2013; Sopharat et al., 2015), limiting rubber production (Wang, 2014). Thus, submitting the rubber tree clone FX 3864, which is widely planted in Brazil, to cyclical water deficit is an alternative to minimize losses, both in seedling establishment and in the latex production phases.

The objective of the present study was to analyze the acclimatization capacity of the photosynthetic machinery of rubber tree seedlings when submitted to water deficit cycles (WDC). To do so, the present study proposed testing the hypothesis that the photosynthetic machinery of rubber tree seedlings submitted to cyclical water deficit will be more resistant to future drought stress. 


\section{MATERIAL AND METHODS}

The study was carried out in a greenhouse under controlled environmental temperature and relative air humidity conditions, in the municipality of Jerônimo Monteiro, ES, Brazil (latitude $20^{\circ} 47^{\prime} 25^{\prime \prime} \mathrm{S}$, longitude $41^{\circ} 23^{\prime} 48^{\prime \prime} \mathrm{W}$, and $120 \mathrm{~m}$ altitude). The experiment was carried out from October 30, 2015 to April 13, 2016, totaling 167 experimental days.

Rubber tree clone FX 3864 seedlings were used, with an average age of 50 days. The seedlings were produced in $980 \mathrm{~cm}^{3}$ tubes with commercial substrate and then transplanted to 21 -liter pots with $17 \mathrm{~kg}$ substrate. The pots were painted with white paint and covered with extruded polystyrene to prevent the substrate from overheating and water evaporation directly from the substrate. Fertilization was applied according to the recommendations for rubber tree (Pereira et al., 2000).

The seedlings grew for 17 days in a greenhouse in full irrigation condition, i.e. substrate moisture at maximum retention capacity (MCR). After this period of seedling establishment, the first cyclical water deficit started. The mean air temperature, mean air vapor pressure deficit, accumulated photosynthetically active radiation and the sum of degrees-days during the water deficit cycles were $26.7^{\circ} \mathrm{C}, 0.30 \mathrm{Kpa}, 1455.54 \mathrm{~mol} \mathrm{~m}^{-2} \mathrm{~s}^{-1}$ and $1855.66^{\circ} \mathrm{C}$, respectively.

The seedlings were separated into four treatments, one with well-watered seedlings (control plants, CT) and three submitted to water deficit cycles (WDC): plants not previously submitted to WDC (OP); plants previously submitted to one WDC (1P); and plants previously submitted to two WDC (2P). The WDC occurred as follows:

- $\quad$ First WDC: 2P plants were subjected to a water deficit for the first time, and plants from $1 \mathrm{P}$ and $\mathrm{OP}$ groups were maintained with soil moisture at field capacity. This cycle lasted 21 days, time to reach photosynthesis $\leq$ zero $(A \leq 0)$;

- Second WDC: 1P plants were subjected to a water deficit condition for the first time, and its cycle lasted 25 days (Time to reach $A \leq 0$ ); $2 \mathrm{P}$ plants were subjected to a water deficit condition for the second time, and its cycle lasted 30 days (Time to reach $A \leq 0$ ); OP plants were maintained with soil moisture at field capacity;

- Third WDC: OP plants were subjected to a water deficit condition for the first time, and its cycle lasted 21 days (Time to reach $A \leq 0$ ); $1 \mathrm{P}$ plants were subjected to a water deficit condition for the second time, and its cycle lasted 30 days (Time to reach $A \leq 0$ ); $2 \mathrm{P}$ plants were subjected to a water deficit condition for the third time, and its cycle lasted 36 days (Time to reach $A \leq 0$ ).

\section{Monitoring the substrate water availability}

Irrigation was carried out based on weighing of the pots with seedlings each two days, replacing the water lost by evapotranspiration. Plants for the control group (OP) treatment were irrigated to achieve the maximum substrate field capacity; the WDCs for the $1 \mathrm{P}$ and $2 \mathrm{P}$ treatments were characterized by two phases: the first or dehydration phase, where the irrigation was suspended until the net plant assimilation rate $(A)$ reached values lower or equal to zero $(A \leq 0)$; and the second or re-hydration phase, where the irrigation was applied to achieve the maximum substrate field capacity. After re-hydration, the plants were kept under condition of maximum substrate field capacity (i.e. fully irrigated), until reaching approximately $90 \%$ of $A$ of the control group, and only then a new water deficit cycle was started. The net carbon assimilation rate $(A \leq 0$ to indicate the end of each WDC for each plants group, and their recovering from the water deficit, i.e. when $A$ in the plants submitted to water deficit reached $90 \%$ of the control group) was measured with a portable infrared gas analyzer (IRGA, Li-Cor model LI-6400) with luminous source fixed at $1000 \mu \mathrm{mol} \mathrm{m}^{-2} \mathrm{~s}^{-1}$ photosynthetically active radiation (PAR) and $400 \mathrm{ppm} \mathrm{CO}_{2}$ concentration in completely opened leaves on the upper third of each plant.

\section{Gas exchanges}

The net assimilation rate $\left(A, \mu \mathrm{mol} \mathrm{CO} \mathrm{Cm}^{-2} \mathrm{~s}^{-1}\right)$, stomatal conductance $\left(g_{\mathrm{s}}, \mathrm{mol} \mathrm{m} \mathrm{m}^{-2} \mathrm{~s}^{-1}\right.$ of $\left.\mathrm{H}_{2} \mathrm{O}\right)$, leaf transpiration $\left(E\right.$, mmol $\mathrm{H}_{2} \mathrm{O} \mathrm{m} \mathrm{m}^{-2} \mathrm{~s}^{-1}$ of $\left.\mathrm{H}_{2} \mathrm{O}\right)$ and intrinsic water use efficiency $\left(A / g_{s}\right)$ 
were measured in all the groups when the first group of plants reached the final WDC3 $(A \leq 0)$ to compare their performance. The measurements were done in completely opened leaves from the upper third median of each plant, in a total of five replications per treatment; these measurements were performed during the WDC3 every three days at 8 am.

\section{Water status}

The relative leaf water content (RWC) was determined at the end of WDC3 using six (6) $1.46 \mathrm{~cm}$ diameter leaf discs per replication (four per treatment) and calculated by the formula:

$$
\operatorname{RWC}(\%)=100 \times[(\mathrm{MF}-\mathrm{MD}) /(\mathrm{MT}-\mathrm{MD})]
$$

Where: MF is the fresh matter obtained by weight shortly after collecting the plant material; MT the turgid matter determined after immersing the disks in water for 24 hours; and MD the dry matter after drying in a chamber at $80^{\circ} \mathrm{C} \pm 5^{\circ} \mathrm{C}$ (Duan et al., 2005).

\section{Photosynthetic pigments}

The photosynthetic pigments were determined only once at the end of the WDC3 in all treatments. Chlorophylls ( $a, b$ and total) and carotenoids were extracted using nine $11.5 \mathrm{~mm}$ diameter leaf discs for each replication (total of four per treatment), placed in test tubes wrapped in aluminum foil and then incubated with $7 \mathrm{~mL}$ dimethyl sulfoxide (DMSO) at $65^{\circ} \mathrm{C}$ for 12 hours. When the plant material became whitish in color, the solution volume was adjusted to $10 \mathrm{~mL}$ with DMSO and transferred to tubes to read the absorbency in a spectrophotometer at wave lengths of $480 \mathrm{~nm}$ for total carotenoids, $665 \mathrm{~nm}$ for chlorophyll $a$ $\left(C h l_{a}\right)$ and $649 \mathrm{~nm}$ for chlorophyll $b\left(C h l_{b}\right)$, following methodology by Daud et al., (2012). The pigment concentrations, expressed in $\mathrm{g} \mathrm{mL}^{-1}$, were calculated according to Wellburn (1994).

\section{Statistics}

A completely randomized experimental design was used. The data observed for the variables studied were tested for normality and homogeneity, and analyses of variances (ANOVA) of the treatments were performed by the F-test (Fisher-Snedecor) ( ${ }^{*} P<0.05$ and ${ }^{n s} P$ $>0.05)$; and the treatment means were compared by the Tukey test $\left({ }^{*} P<0.05\right.$ and $\left.{ }^{n s} p>0.05\right)$ for the pigments and gas exchanges and by the Student's t-test ( ${ }^{*} P<0.05$ and ${ }^{n s} P>0.05$ ) for RWC. The performance of the physiological data related to the percentage of water available in the substrate during the last water deficit cycle was assessed by simple linear regression analysis $(\hat{y}=a+b x)$, with the fit of the straight lines to the data set. The equation coefficients were tested by the Student's t-test ( ${ }^{*} P<0.05$ and ${ }^{n s} P>0.05$ ) to determine whether there was a relation between the variables and the variation in $\mathrm{y}$ for a given variation in $\mathrm{x}$. The statistical analyses were performed using the R software program (R Core Team, 2018).

\section{RESULTS AND DISCUSSION}

The WDC3 duration was different among the treatments studied. Plants that were not previously submitted to WDC (OP) finished this cycle after 21 days, before the other plant groups, presenting intense leaf abscission. The plants with pre-exposure to water stress (1P) finished their cycle after 30 days, and those in treatment $2 \mathrm{P}$ (two pre-exposures) after 36 days of dehydration.

Rubber tree plants submitted to two previous water deficit cycles in the substrate (2P) acclimatized their photosynthetic machinery more efficiently, and maintained their cell turgidity, high photosynthesis rates and high photosynthetic pigment concentrations even at low substrate water availability percentage, compared to plants subjected to one or no 
previous stress, thereby confirming that the photosynthetic machinery of rubber tree seedlings submitted to cyclical water deficit will be more resistant to future drought stress.

\section{Gas exchanges: characterization and effect on the treatments}

The gas exchange values of the groups measured at 21 days of the WDC3, when the OP group reached $A$ values close to zero, presented significant differences among the treatments for the physiological variables $A, g_{s}, E$ and $A / g_{s}$ (Figure 1). The gas exchange variables showed that there was an acclimatization of the photosynthetic machinery of the seedlings after being subjected to two water deficit cycles, because it was observed that $A, g s, E$ and $A / g s$ in $2 \mathrm{P}$ presented similar behavior to the control treatment after going through $\mathrm{OP}$ and $1 \mathrm{P}$. The net $\mathrm{CO}_{2}$ assimilation rate (Figure $1 \mathrm{~A}$ ) of the seedlings submitted to three water deficient cycles (treatment 2P) was approximately $91 \%$ higher than those of the two-cycle treatment (1P). The results reveal that the seedlings of $\mathrm{OP}$ and $1 \mathrm{P}$ treatments limited stomatal opening, since the stomatal conductance (Figure 1B) and transpiration (Figure 1C) variables were significantly reduced. In addition, the intrinsic efficiency of water use (Figure 1D) was significantly reduced, especially in the first water deficient cycle (OP).
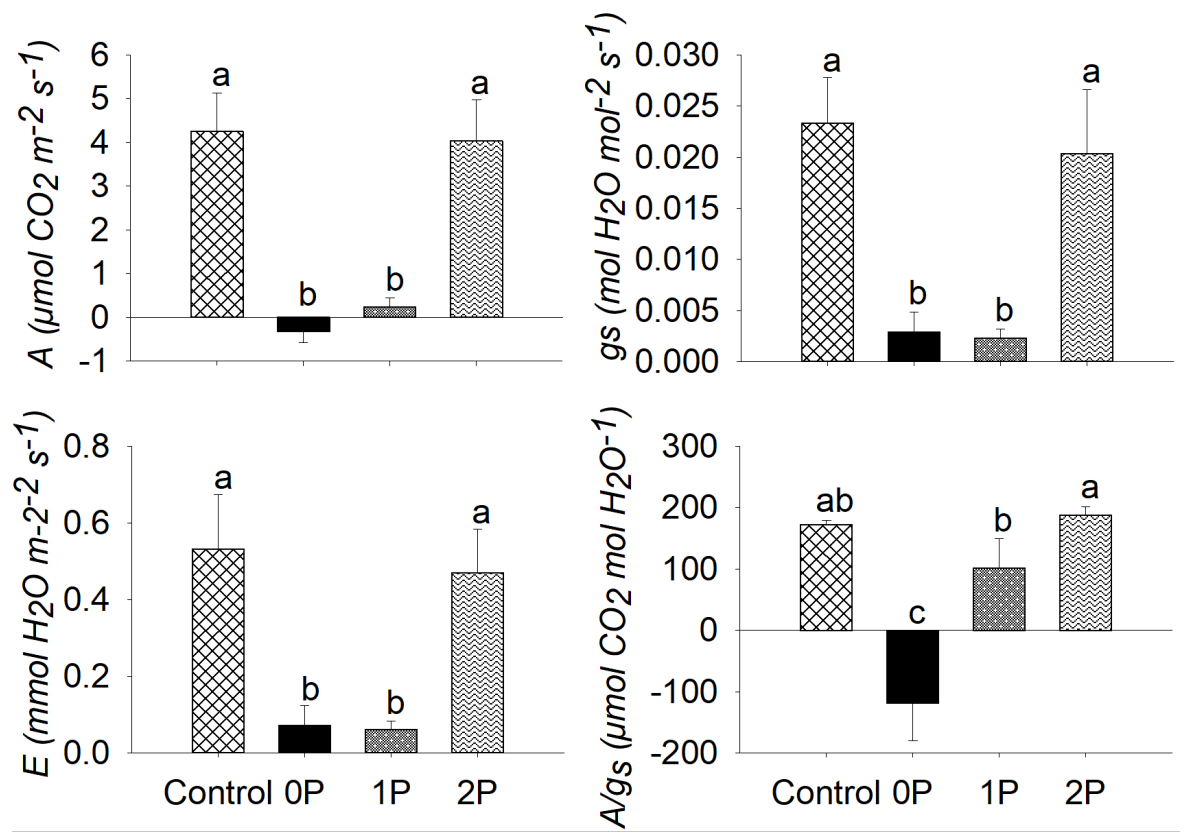

Figure 1. Net carbon assimilation rate $(A)$, stomatal conductance $(g s)$, transpiration $(E)$ and intrinsic water use efficiency $(A / g s)$ in rubber tree clone FX 3864 seedlings 21 days after undergoing the third water deficit cycle (WDC3) between 8 and 9 o'clock in the morning, in a greenhouse in the municipality of Jerônimo Monteiro, ES, Brazil. The values observed are the means \pm standard deviation $(n=5)$. Means followed by the same letter in the columns do not differ statistically (F-Test and Tukey's Test, $\mathrm{P} \leq 0.05$ ). Control - constantly irrigated; OP - not previously submitted to any WDC; $1 \mathrm{P}$-previously submitted to one WDC; and 2P -previously submitted to two WDC.

\section{Water relationships and physiology}

The relationship between the gas exchange variables and the percentage of water availability (\%WA) in the substrate during WDC3 showed a difference among the treatments for $A, g_{s}$ and $E$ (Figure 2). All the treatments decreased in value for these variables as the \%WA in the substrate decreased with dehydration. According to the relationship obtained, plants submitted to the $2 \mathrm{P}$ treatment kept a positive carbon balance of up to $15 \%$ of $\% \mathrm{WA}$ in the substrate, while the $1 \mathrm{P}$ and $\mathrm{OP}$ plants kept $A>0$ up to $28 \%$ and $48 \% \% \mathrm{WA}$ in the substrate, respectively. 

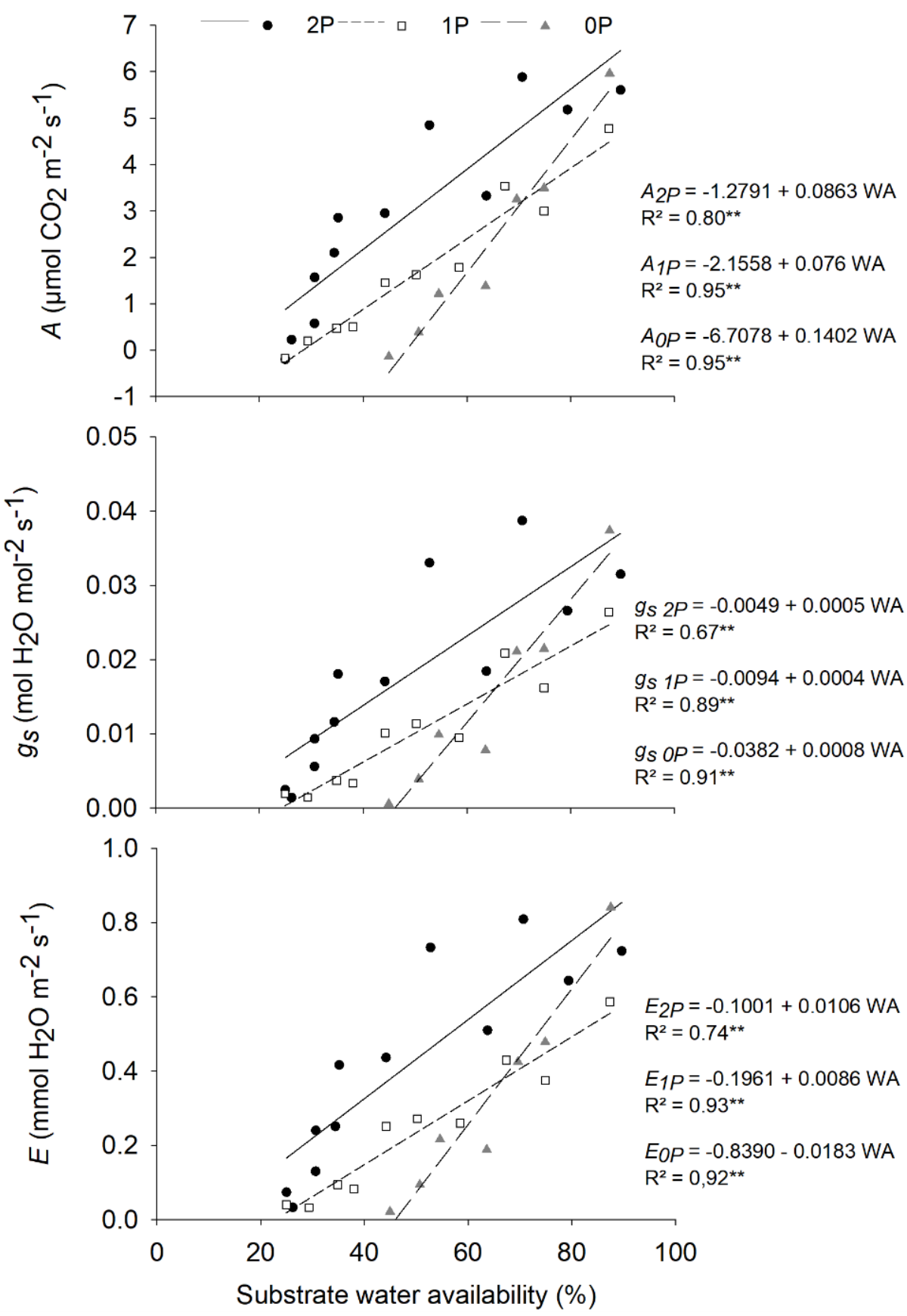

Figure 2. Relationship between net carbon assimilation rate $(A)$, stomatal conductance $\left(g_{s}\right)$ and transpiration $(E)$ with the percentage of water availability (\%WA) in the soil in rubber tree FX 3864 clone seedlings submitted to the third water deficit cycle (WDC3) in a greenhouse in the municipality of Jerônimo Monteiro, ES, Brazil. The values observed are the means of the treatments $(n=6)$. The asterisks $\left(^{* *}\right)$ indicate significant effect of the parameters of the regression equations (F-Test and Student's t-test, $P \leq 0.5$ ). Control - constantly irrigated; OP - not previously submitted to any WDC; $1 \mathrm{P}$ previously submitted to one WDC; and $2 \mathrm{P}$-previously submitted to two WDCs.

The high turgidity levels in the $2 \mathrm{P}$ plants, similar to those observed in the control plants, indicated that there were modifications in the leaf cell wall so they became more elastic and reached more negative water potentials. Furthermore, they remained turgid with effective osmotic adjustment (Silva et al., 2010), even with closed stomata and at very low substrate water level. Thus, osmotic regulation is indicated to be one of the tolerance process mechanisms of this clone of rubber tree to water deficit (Wang, 2014). 
Tolerance to water stress can also be related to hormone metabolism and synthesis, especially to abscisic acid (ABA), which regulates processes of adaptive responses to water stress, such as stomatal closure (Cutler et al., 2010; Urano et al., 2017). In this sense, plants pre-exposed to more than one WDC may show higher ABA concentration than plants that were not previously exposed (Neves et al., 2017), but with less sensitivity of the stomata complex to ABA to stress, so that the stomata remain open or partially open for longer than those which did not experimented any water deficit (Marchin et al., 2016; Virlouvet \& Fromm, 2015). Therefore, the plants lose less water by transpiration when submitted to water deficit; otherwise, the water deficit would quickly cause stomata closure, as observed in OP plants not previously submitted to any WDC (Marchin et al., 2016; Virlouvet \& Fromm, 2015).

In contrast, there was quick stomatal conductance and a transpiration reduction with the decrease in the \%WA. The plants in treatment $1 \mathrm{P}$ showed intermediate performance regarding the $A, g_{s}$ and $E$ values, compared to the $2 \mathrm{P}$ and OP plants, as can be observed by the slope of the lines and equations of the models.

Regarding the relative water content (RWC) in the $\mathrm{OP}, 1 \mathrm{P}$ and $2 \mathrm{P}$ treatments compared with the control plants when each treatment ended its cycle, it was observed that the $2 \mathrm{P}$ treatment plants had a similar leaf water supply to the control group (Figure 3). The greatest reduction in the relative water content was observed in $1 \mathrm{P}$, where the seedlings reduced approximately $39 \%$ of the RWC values. When analyzing the 2P seedlings, it is clear that they were acclimatized and were not statistically different from the control treatment.

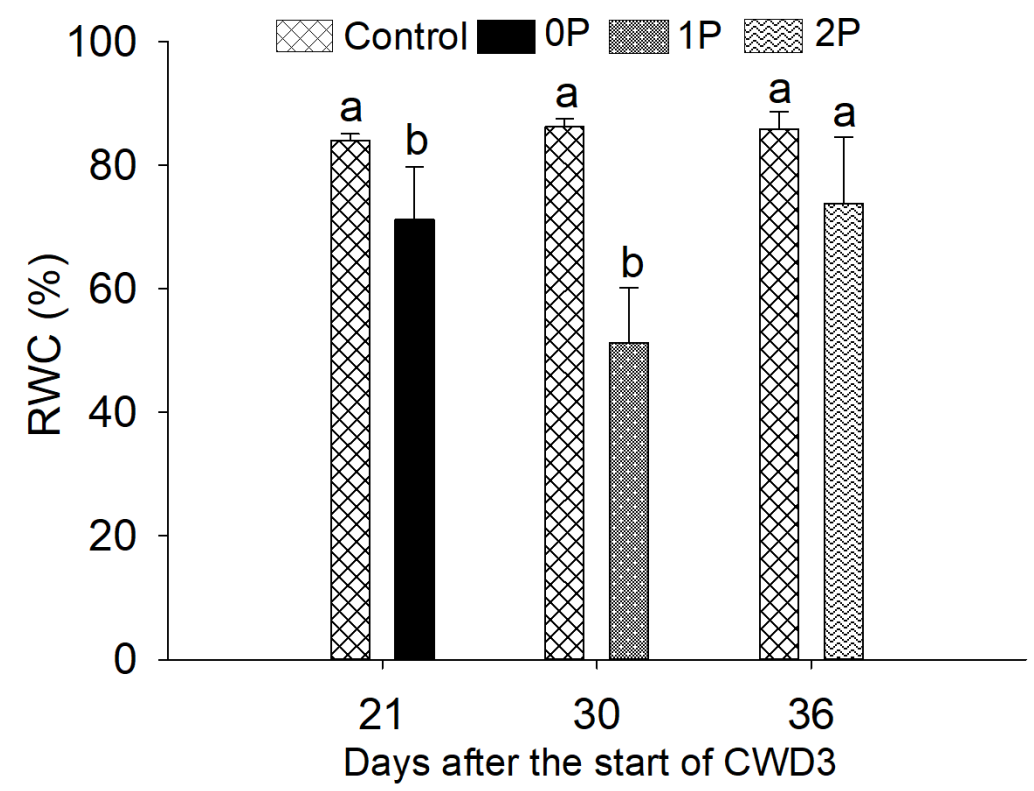

Figure 3. Relative water content (RWC) in leaves of the rubber tree clone FX 3864 seedlings at the end of the third water deficit cycle (21, 30 and 36 days after the start of the WDC3, for groups OP, 1P and 2P, respectively) compared with the plant controls in a greenhouse in the municipality of Jerônimo Monteiro, ES, Brazil. The values observed are the means \pm standard deviation $(n=4)$. Means followed by the same letter in the days do not differ statistically among the WDC (F-Test and Student's t-test, $P \leq$

0.05). Control - constantly irrigated; OP - not previously submitted to any WDC; $1 \mathrm{P}$-previously submitted to one WDC; and 2P -previously submitted to two WDC.

\section{Photosynthetic pigments}

Analysis of variance showed that at the end of the experiment the concentration of photosynthetic pigment chlorophyll $a\left(\mathrm{Chl}_{a}\right)$ was the highest in the plants submitted to two previous WDC (2P) and also favored the high concentration of total chlorophyll (Chl totais) (Figure 4), although the chlorophyll $b\left(\mathrm{Ch}_{b}\right)$ content was similar among all the treatments. The carotenoid contents ( $\mathrm{Car}$ ) were higher and similar between the 2P and $1 \mathrm{P}$ treatments, although the concentration in the latter did not differ from the OP and control plant treatments. 


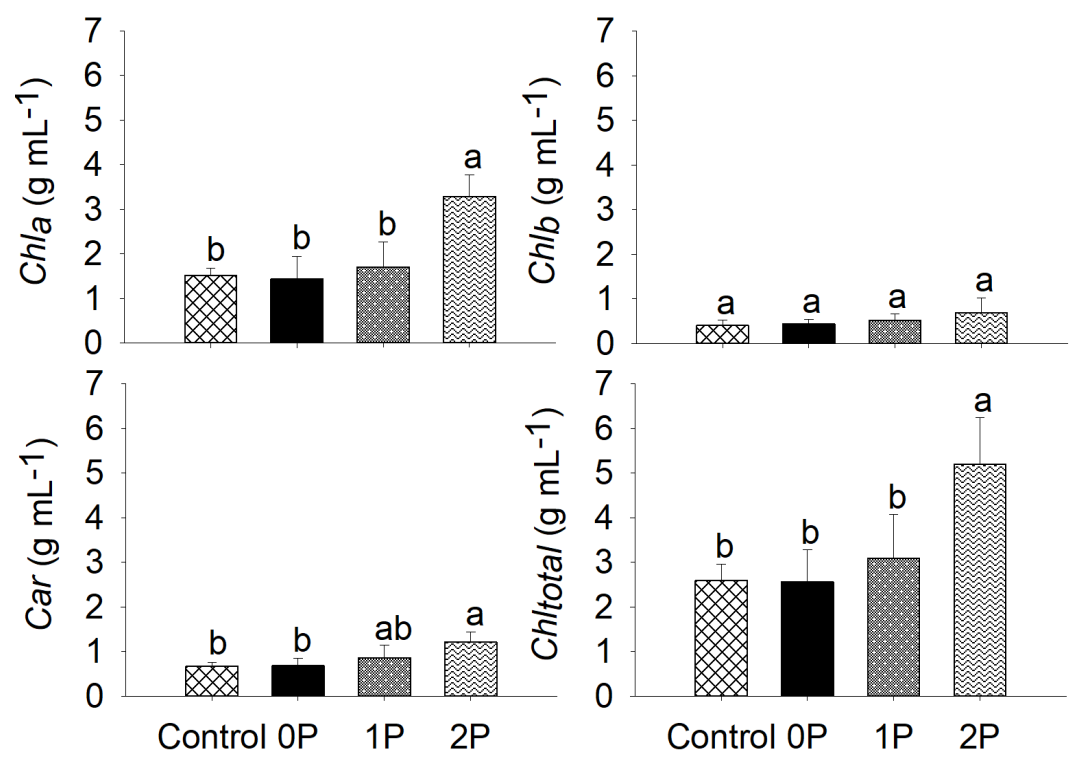

Figure 4. Content of photosynthetic pigments chlorophyll a (Chla), chlorophyll b (Chlb), carotenoids (Car) and total chlorophylls (Ch/total) in rubber tree clone FX 3864 seedlings submitted to water deficient cycles (WDC) in a greenhouse in the municipality of Jerônimo Monteiro, ES, at the end of the third cycle of each treatment (21, 30 and 36 days after the beginning of cycle 3, for groups OP, $1 \mathrm{P}$ and $2 \mathrm{P}$, respectively). The observed values are the means \pm standard deviation $(n=4)$. Averages followed by the same letter in the columns do not differ statistically (F-Test and Tukey's test, $P \leq 0.05$ ). Control constantly irrigated; OP - not previously submitted to WDC; $1 \mathrm{P}$ - previously submitted to one WDC; and $2 \mathrm{P}$ - previously submitted to two WDCs.

At the end of WDC3, the plants in 2P treatment accumulated high photosynthetic pigment contents, mainly carotenoids and chlorophyll $a\left(\mathrm{Ch}_{a}\right)$, which significantly influenced the total chlorophyll content $\left(\mathrm{Ch}_{\text {totais }}\right)$. These findings indicated that thylakoid membranes were not damaged in the plants submitted to successive WDC (Streit et al., 2005). Also, a possible accumulation of carotenoids in the 2P plants may be a defense strategy of the leaf tissue cells, contributing to a decrease of the effects of chronic photo-inhibition, and increase the capacity to dissipate energy excess which minimizes the damage caused by oxidative stress (Correia et al., 2014; Jaleel et al., 2009; Liberato et al., 2006).

The maintenance of cell turgidity in the $2 \mathrm{P}$ plants due to osmotic adjustments and cell elasticity favored better use of the water in the substrate so that $A$ remained positive at low substrate \%WA. Although water deficit reduced gas exchanges in all the treatments, 2P plants still presented higher $A$, gs and $E$ values than the OP and $1 \mathrm{P}$ plants for the same \%WA value present in the substrate. This shows that the $2 \mathrm{P}$ treatment plants optimized water absorption from the substrate maintaining high transpiration $(E)$, which was due to the high-water use efficiency.

The gas exchange responses showed that when the plants were exposed to at least one previous water deficit, there was an acclimatization of the plants which improves their performance when submitted to a new stress. Plants submitted to no previous WDC (OP) reached low values of $A, g_{s} E$ and $A / g_{s}$ quicker and also cell relative water content. Thus, there was more cell damage which culminated in leaf dehydration, senescence and abscission with a decrease in substrate water availability in the OP plants compared to the other treatments. This stomatal closing is one of the first responses in defense to water deficit to reduce the excessive water losses, however it also reduces carbon assimilation in the leaf, which is a biochemical limitation of the photosynthetic machinery (Chaves et al., 2003; Silva et al., 2004; Perez-Martin et al., 2014).

Our findings suggest that the WDC generated an acclimatization in the 2P plants which caused an alteration in the physiological responses in the face of dehydration (Bruce et al., 2007; Menezes-Silva et al., 2017; Virlouvet \& Fromm, 2015). This acclimatization favored keeping positive $A$ rates and leaf turgidity. Future studies are still needed to establish 
molecular mechanisms by which the plants store information on exposure to stress caused by biotic and abiotic variables. However, some evidence can be found in studies such as that by Ding and collaborators (2012) on Arabidopsis thaliana plants, who reported that there was a high expression of the genes attributed to drought tolerance capacity in each water deficit cycle compared to the non-stressed plants. These responses enabled $A$. thaliana plants to intensify their defense and recover from the stressful factor.

\section{CONCLUSION}

Our findings indicated that the rubber tree clone FX 3864 seedlings were able to maintain the cell water status for a longer time due to the photosynthetic machinery acclimatization when previously submitted to two water deficit cycles. Thus, from the practical point of view, submitting rubber tree seedlings at the first development stage to controlled periods of moderate drought may contribute to better hardening in nurseries and thus increase their ability to acclimatize more quickly to later drought events, decreasing the mortality rate of the seedling in the field just after planting, and minimizing costs with replanting.

\section{ACKNOWLEDGEMENTS}

This study was partly financed by the Coordenação de Aperfeiçoamento de Pessoal de Nível Superior - Brasil (CAPES) - Finance Code 001.

\section{REFERÊNCIAS}

Alvares, C. A., Stape, J. L., Sentelhas, P. C., Gonçalves, J. L. G., \& Sparovek, G. (2013). Köppen's climate classification map for Brazil. Meteorologische Zeitschri, 22(6), 711-728. http://dx.doi.org/10.1127/0941-2948/2013/0507.

Amaral, G. C., Pezzopane, J. E. M., Nóia Júnior, R. S., Fonseca, M. D. S., Toledo, J. V., Xavier, T. M. T., Oliveira, B. S., Martínez, M. F., Jerônimo Júnior, R. A. C., \& Gonçalves, E. O. (2021). Ecophysiology of Pilocarpus microphyllus in response to temperature, water availability and vapour pressure deficit. Trees, 35(2), 543-555. http://dx.doi.org/10.1007/s00468-020-02055-x.

Bruce, T. J. A., Matthes, M. C., Napier, J. A., \& Pickett, J. A. (2007). Stressful “memories” of plants: evidence and possible mechanisms. Plant Science, 173(6), 603-608. http://dx.doi.org/10.1016/j.plantsci.2007.09.002.

Chaves, M. M., Maroco, J. P., \& Pereira, J. S. (2003). Understanding plant responses to drought - from genes to the whole plant. Functional Plant Biology, 30(3), 239-264. http://dx.doi.org/10.1071/FP02076. PMid:32689007.

Clermont-Dauphin, C., Suvannang, N., Hammecker, C., Cheylan, V., Pongwichian, P. F., \& Do, F. C. (2013). Unexpected absence of control of rubber tree growth by soil water shortage in dry subhumid climate. Agronomy for Sustainable Development, 33(3), 531-538. http://dx.doi.org/10.1007/s13593-012-0129-2.

Correia, B., Pintó-Marijuan, M., Neves, L., Brossa, R., Dias, M. C., Costa, A., Castro, B. B., Araújo, C., Santos, C., Chaves, M. M., \& Pinto, G. (2014). Water stress and recovery in the performance of two Eucalyptus globulus clones: physiological and biochemical profiles. Physiologia Plantarum, 150(4), 580-592. http://dx.doi.org/10.1111/ppl.12110. PMid:24117924.

Cutler, S. R., Rodriguez, P. L., Finkelstein, R. R., \& Abrams, S. R. (2010). Abscisic acid: emergence of a core signaling network. Annual Review of Plant Biology, 61(1), 651-679. http://dx.doi.org/10.1146/annurevarplant-042809-112122. PMid:20192755.

Daud, R. D., Conforto, E. C., \& Feres, R. J. F. (2012). Changes in leaf physiology caused by Calacarus heveae (Acari, Eriophyidae) on rubber tree. Experimental and Applied Acarology, 57(2), 127-137. http://dx.doi.org/10.1007/s10493-012-9552-y. PMid:22527832.

Ding, Y., Fromm, M., \& Avramova, Z. (2012). Multiple exposures to drought 'train' transcriptional responses in Arabidopsis. Nature Communications, 3, 740. http://dx.doi.org/10.1038/ncomms1732.

Duan, B., Lu, Y., Yin, C., Junttila, O., \& Li, C. (2005). Physiological responses to drought and shade in two contrasting Picea asperata populations. Physiologia Plantarum, 124(4), 476-484. http://dx.doi.org/10.1111/j.1399-3054.2005.00535.x. 
Elli, E. F., Sentelhas, P. C., Freitas, C. H., Carneiro, R. L., \& Alvares, C. A. (2019). Assessing the growth gaps of Eucalyptus plantations in Brazil - magnitudes, causes and possible mitigation strategies. Forest Ecology and Management, 451, 117464. http://dx.doi.org/10.1016/j.foreco.2019.117464.

Freitas, C. H., Elli, E. F., \& Sentelhas, P. C. (2021). On-farm assessment of eucalypt yield gaps: a case study for the producing areas of the state of Minas Gerais, Brazil. International Journal of Biometeorology, 65(10), 1659-1673. http://dx.doi.org/10.1007/s00484-021-02120-1. PMid:33884447.

Intergovernmental Panel on Climate Change - IPCC. (2021). Climate change 2021: the physical science basis. Cambridge: Cambridge University Press.

Jaleel, C. A., Manivannan, P., Wahid, A., Farooq, M., Somasundaram, R., \& Panneerselvam, R. (2009). Drought stress in plants: a review on morphological characteristics and pigments composition. International Journal of Agriculture and Biology, 11(1), 100-105.

Kimball, B. A., Morris, C. F., Pinter Junior, P. J., Wall, G. W., Hunsaker, D. J., Adamsen, F. J., LaMorte, R. L., Leavitt, S. W., Thompson, T. L., Matthias, A. D., \& Brooks, T. J. (2001). Elevated $\mathrm{CO}_{2}$, drought and soil nitrogen effects on wheat grain quality. The New Phytologist, 150(2), 295-303. http://dx.doi.org/10.1046/j.1469-8137.2001.00107.x.

Kositsup, B., Montpied, P., Kasemsap, P., Thaler, P., Améglio, T., \& Dreyer, E. (2009). Photosynthetic capacity and temperature responses of photosynthesis of rubber trees (Hevea brasiliensis Müll. Arg.) acclimate to changes in ambient temperatures. Trees, 23(2), 357-365. http://dx.doi.org/10.1007/s00468-008-0284-x.

Liberato, M. A. R., Gonçalves, J. F. C., Chevreuil, L. R., Nina Junior, A. R., Fernandes, A. V., \& Santos Junior, U. M. (2006). Leaf water potential, gas exchange and chlorophyll a fluorescence in acariquara seedlings (Minquartia guianensis Aubl.) under water stress and recovery. Brazilian Journal of Plant Physiology, 18(2), 315-323. http://dx.doi.org/10.1590/S1677-04202006000200008.

Marchin, R. M., Broadhead, A. A., Bostic, L. E., Dunn, R. R., \& Hoffmann, W. A. (2016). Stomatal acclimation to vapour pressure deficit doubles transpiration of small tree seedlings with warming. Plant. Plant, Cell \& Environment, 39(10), 2221-2234. PMid:27392307. http://dx.doi.org/10.1111/pce.12790.

Menezes-Silva, P. E., Sanglard, L. M. V. P., Ávila, R. T., Morais, L. E., Martins, S. C. V., Nobres, P., Patreze, C. M., Ferreira, M., Araújo, W. L., Fernie, A. R., \& DaMatta, F. M. (2017). Photosynthetic and metabolic acclimation to repeated drought events play key roles in drought tolerance in coffee. Journal of Experimental Botany, 68(15), 4309-4322. PMid:28922767. http://dx.doi.org/10.1093/jxb/erx211.

Neves, D. M., Almeida, L. A. H., Santana-Vieira, D. D. S., Freschi, L., Ferreira, C. F., Soares Filho, W. S., Costa, M. G. C., Micheli, F., Coelho Filho, M. A., \& Gesteira, A. S. (2017). Recurrent water deficit causes epigenetic and hormonal changes in citrus plants. Scientific Reports, 7(1), 13684. http://dx.doi.org/10.1038/s41598-017-14161-x. PMid:29057930.

Nóia Júnior, R. S., Amaral, G. C., Pezzopane, J. E. M., Fonseca, M. D. S., Silva, A. P. C., \& Xavier, T. M. T. (2020a). Ecophysiological acclimatization to cyclic water stress in Eucalyptus. Journal of Forestry Research, 31(3), 797-806. http://dx.doi.org/10.1007/s11676-019-00926-9.

Nóia Júnior, R. S., Fraisse, C. W., Karrei, M. A. S., Cerbaro, V. A., \& Perondi, D. (2020b). Effects of the El Niño Southern Oscillation phenomenon and sowing dates on soybean yield and on the occurrence of extreme weather events in southern Brazil. Agricultural and Forest Meteorology, 290(15), 108038. http://dx.doi.org/10.1016/j.agrformet.2020.108038.

Pereira, A. V., Pereira, E. B. C., Fialho, J. F., Andrade, L. R. M., \& Junqueira, N. T. V. (2000). Adubação de mudas e jardim clonal de seringueira. Planaltina: Embrapa Cerrados.

Perez-Martin, A., Michelazzo, C., Torres-Ruiz, J. M., Flexas, J., Fernández, J. E., Sebastiani, L., \& DiazEspejo, A. (2014). Regulation of photosynthesis and stomatal and mesophyll conductance under water stress and recovery in olive trees: correlation with gene expression of carbonic anhydrase and aquaporins. Journal of Experimental Botany, 65(12), 3143-3156. http://dx.doi.org/10.1093/jxb/eru160. PMid:24799563.

R Core Team. (2018). R: A language and environment for statistical computing. Vienna: R Foundation for Statistical Computing.

Reich, P. B., Sendall, K. M., Stefanski, A., Wei, X., Rich, R. L., \& Montgomery, R. A. (2016). Boreal and temperate trees show strong acclimation of respiration to warming. Nature, 531(7596), 633-636. http://dx.doi.org/10.1038/nature17142. PMid:26982730.

Silva, E. N., Ferreira-Silva, S. L., Viégas, R. A., \& Silveira, J. A. G. (2010). The role of organic and inorganic solutes in the osmotic adjustment of drought-stressed Jatropha curcas plants. Environmental and Experimental Botany, 69(3), 279-285. http://dx.doi.org/10.1016/j.envexpbot.2010.05.001. 
Silva, F. C., Shvaleva, A., Maroco, J. P., Almeida, M. H., Chaves, M. M., \& Pereira, J. S. (2004). Responses to water stress in two Eucalyptus globulus clones differing in drought tolerance. Tree Physiology, 24(10), 1165-1172. http://dx.doi.org/10.1093/treephys/24.10.1165. PMid:15294763.

Sopharat, J., Gay, F., Thaler, P., Sdoodee, S., Ayutthaya, S. I., Tanavud, C., Hammecker, C., \& Do, F. C. (2015). A simple framework to analyze water constraints on seasonal transpiration in rubber tree (Hevea brasiliensis) plantations. Frontiers in Plant Science, 5, 753. http://dx.doi.org/10.3389/fpls.2014.00753. PMid:25610443.

Streit, N. M., Canterle, L. P., Canto, M. W. D., \& Hecktheuer, L. H. H. (2005). The chlorophylls. Ciência Rural, 35(3), 748-755. http://dx.doi.org/10.1590/S0103-84782005000300043.

Urano, K., Maruyama, K., Jikumaru, Y., Kamiya, Y., Yamaguchi-Shinozaki, K., \& Shinozaki, K. (2017). Analysis of plant hormone profiles in response to moderate dehydration stress. The Plant Journal, 90(1), 17-36. http://dx.doi.org/10.1111/tpj.13460. PMid:27995695.

Venkatachalam, P., Thulaseedharan, A., \& Raghothama, K. (2009). Molecular identification and characterization of a gene associated with the onset of Tapping Panel Dryness (TPD) syndrome in rubber Tree (Hevea brasiliensis Muell.) by mRNA differential display. Molecular Biotechnology, 41(1), 42-52. http://dx.doi.org/10.1007/s12033-008-9095-y. PMid:18726169.

Virlouvet, L., \& Fromm, M. (2015). Physiological and transcriptional memory in guard cells during repetitive dehydration stress. The New Phytologist, 205(2), 596-607. http://dx.doi.org/10.1111/nph.13080.PMid:25345749.

Walter, J., Nagy, L., Hein, R., Rascher, U., Beierkuhnlein, C., Willner, E., \& Jentsch, A. (2011). Do plants remember drought? Hints towards a drought-memory in grasses. Environmental and Experimental Botany, 71(1), 34-40. http://dx.doi.org/10.1016/j.envexpbot.2010.10.020.

Wang, L. (2014). Physiological and molecular responses to drought stress in rubber tree (Hevea brasiliensis Muell. Arg.). Plant Physiology and Biochemistry, 83, 243-249. http://dx.doi.org/10.1016/j.plaphy.2014.08.012. PMid:25194774.

Wellburn, A. R. (1994). The spectral determination of chlorophylls $a$ and $b$, as well as total carotenoids, using various solvents with spectrophotometers of different resolution. Journal of Plant Physiology, 144(3), 307-313. http://dx.doi.org/10.1016/S0176-1617(11)81192-2.

Authors' contributions: JEMP: funding acquisition, methodology and conceptualization; JMQ, MDSF, RSNJ and JSV: project administration, methodology, formal analysis and Writing - original draft; MDSF, RSNJ and GCA: conceptualization, methodology, formal analysis and Writing - review \& editing; TMTX and PCV: supervision and methodology. 